\title{
Gambaran Proses Pembelajaran E-learning Mahasiswa Fakultas Kedokteran Universitas YARSI Jakarta
}

\section{Overview of the E-learning Process of The Medical Students at YARSI University Jakarta}

\author{
Nur Asiah \\ Department of Nutrition, Faculty of Medicine, YARSI University, Jakarta \\ Jalan Letjen. Suprapto, Cempaka Putih, Jakarta 10510 \\ Telephone (021) 4206674, 4206675, 4206676 \\ Correspondence: nur.asiah@yarsi.ac.id
}

\begin{abstract}
Abstrak
Pendahuluan: Pandemi covid-19 telah menuntut pergutuan tinggi untuk melaksanakan pembelajaran online. Tujuan penelitian ini adalah untuk mengetahui gambaran proses pembelajaran secara e-learning pada mahasiswa Fakultas Kedokteran Universitas YARSI Jakarta pada bulan September-November 2020. Metode: Desain penelitian bersifat cross sectional dengan cara pengumpulan data melalui kuesioner. Data yang terkumpul berasal dari 220 orang mahasiswa semester V yang sedang mengikuti Blok Endokrin, Metabolik dan Nutrisi. Pertanyaan yang diajukan terdiri dari pertanyaan terbuka dengan jawaban singkat dan pertanyaan pilihan ganda. Hasil: Hasil penelitian menunjukkan $40 \%$ mahasiswa menyatakan penyampaian materi kuliah diserap dengan baik, 48\% mahasiswa mempersiapkan materi sebelum e-learning, 47\% mahasiswa memiliki pengaturan waktu yang baik dan 36\% mahasiswa berkonsentrasi selama 2-3 jam. Keluhan kesehatan terbanyak adalah kekakuan leher dan otot serta pusing (40\%). Sebanyak $47 \%$ mahasiswa menyatakan mudah mendapatkan materi kuliah. Metode belajar secara berkelompok merupakan pilihan utama (69\%), meskipun 56\% mahasiswa lebih menyukai tatap muka langsung dibandingkan e-learning. Simpulan: E-learning pada mahasiswa FK YARSI Jakarta berlangsung lancar dengan penyerapan materi yang baik dan kemudahan mengakses materi. Kemandirian mahasiswa terlihat berupa persiapan, pengaturan kegiatan harian dan sistem belajar kelompok, meskipun terdapat keluhan kesehatan, terbatasnya konsentrasi dan tatap muka langsung yang lebih disukai dibandingkan e-learning.
\end{abstract}

Kata kunci: covid-19; Mahasiswa kedokteran; e-learning

\section{Abstract}

Background: The coronavirus disease (COVID-19) pandemic forced many universities to apply online learning. This study aimed to break down the online learning process faced by the medical students of YARSI University Jakarta from September-November 2020, as well as to study effective and optimal online learning. Method: The design of this research is cross-sectional. The data were collected using questionnaires. We collected data from 220 medical students who were following endocrinology, nutrition, and metabolism system from September to November 2020. The questions 
consisted of open questions with short answers and multiple choices questions. Result: The medical students got the materials well (40\%). Almost half of them (48\%) prepared for e-learning at-least 10-15 minutes before. They arranged their daily time well (47\%), so the e-learning processed did not disturb their daily activities. Their full concentration during e-learning took only 2-3 hours (36\%). The health problems during e-learning processed were stiff neck, dizzy and muscle stiffness (40\%). It was easy to get the materials from the teachers, e-books, and journals (47\%). Most students enjoyed the study groups to solve the problems during e-learning (69\%). Nevertheless, they said that they prefer face-toface learning to e-learning (56\%). Conclusion: The E-learning process in YARSI Medical students ran well due to the convenience and easiness of getting the study materials. The students' independence were manifest in good preparation, well arrangement of daily activity and the making of study grcups, although they had many health problems, limited concentration, and prefer offline lectures than elearning.

Keywords: covid-19; e-learning; medical students

\section{Pendahuluan}

Melalui Kementerian Pendidikan dan Kebudayaan, pemerintah telah melarang perguruan tinggi untuk melaksanakan perkuliahan tatap muka (konvensional) dan memerintahkan untuk menyelenggarakan perkuliahan atau pembelajaran secara daring berdasarkan Surat Edaran Direktur Jendral Pendidikan Tinggi Kementrian Pendidikan dan Kebudayaan Republik Indonesia No.1 tahun 2020 (www.kemdikbud.go.id). Perguruan tinggi dituntut untuk dapat menyelenggarakan pembelajaran secara daring atau online (Firman dan Rahman, 2020). E-learning adalah metode penyampaian materi perkuliahan secara online yang proses tatap mukanya sedikit (Poon, 2013). Dalam masa pandemi Covid-19 ini, metode elearning merupakan metode pilihan untuk pelaksanaan pendidikan di perguruan tinggi demi mengurangi risiko penularan virus tersebut.

Pembelajaran e-learning selama pandemi covid-19 di Fakultas Kedokteran Universitas YARSI belum banyak diteliti, padahal dengan mengetahui faktor-faktor yang berkontribusi di dalamnya dapat dievaluasi sistem tersebut. Penelitian ini bertujuan untuk mengetahui gambaran persepsi mahasiswa dalam pembelajaran e-learning pada mahasiswa Fakultas Kedokteran Universitas YARSI Jakarta.

Perilaku belajar mahasiswa secara elearning yang dikenal dengan istilah daring (dalam jaringan), sangat mementingkan kemandirian untuk kesuksesannya. Keuntungan dari sistem e-learning ini adalah kebebasan akan waktu dan pencarian informasi yang tidak ada batas. Mahasiswa akan melakukan tindakan positif jika mahasiswa merasa puas setelah berinteraksi dengan website tersebut. Perasaan puas juga dipengaruhi oleh motivasi, interaksi selama proses belajar, konten kurikulum ajar, dan literasi digital. Perasaan puas akan menunjang kesuksesan belajar.

Pembelajaran daring telah banyak dilakukan dalam konteks perguruan tinggi, terbukti dari beberapa penelitian yang menjelaskan hal tersebut. Pembelajaran daring memberikan manfaat dalam membantu menyediakan akses belajar bagi semua orang, sehingga menghapus hambatan secara fisik sebagai faktor untuk belajar dalam ruang lingkup 
kelas, bahkan hal tersebut dipandang sebagai sesuatu yang efektif untuk diterapkan khususnya dalam perguruan tinggi. Pembelajaran daring memungkinkan mahasiswa memiliki keleluasaan waktu belajar sehingga dapat belajar kapanpun dan dimanapun. Selain itu, mahasiswa dapat berinteraksi dengan dosen menggunakan beberapa aplikasi seperti e-classroom, video conference, telepon atau live chat, zoom maupun melalui whatsapp group.

\section{Bahan dan Metoda Penelitian}

Penelitian ini menggunakan pendekatan kuantitatif dengan desain cross sectional. Partisipasi pada penelitian ini adalah mahasiswa Fakultas Kedokteran Semester $\mathrm{V}$ Universitas YARSI Jakarta yang sedang mengikuti perkuliahan Blok Endokrin, Metabolik dan Nutrisi pada bulan September-November 2020. Blok Endokrin, Metabolik dan Nutrisi melaksanakan perkuliahan online selama 60 jam, dan praktikum. Blok ini mempelajari gangguan kesehatan yang berhubungan dengan hormon dan sistem metabloisme tubuh. Banyaknya bagian yang terlibat dalam blok ini yaitu anatomi, histologi, fisiologi, farmakologi, biokimia, gizi, mikrobiologi, ilmu penyakit dalam, ilmu kesehatan anak, ilmu penyakit mata, obstetri dan ginekologi, bedah, patologi klinik, patologi anatomi, ilmu agama, gigi mulut dan neurologi. Perkuliahan yang disampaikan selama 6 minggu sehingga dibutuhkan evaluasi mengenai persepsi mahasiswa terhadap sistem perkuliahan secara online. Pertanyaan yang diajukan terdiri dari pertanyaan terbuka dengan jawaban singkat dan pertanyaan pilihan ganda.

Pertimbangan dalam mengikutsertakan mahasiswa pada awal semester ini adalah setelah libur awal tahun ajaran baru diharapkan mahasiswa dalam kondisi sehat dengan penuh semangat dalam mengikuti perkuliahan di awal semester meski secara daring. Kriteria inklusi adalah mahasiswa Fakultas Kedokteran Universitas YARSI semester $\mathrm{V}$ yang sedang mengambil mata kuliah Blok Endokrin, Metabolik dan Nutrisi, melakukan pembelajaran jarak jauh atau sistem e-learning dan bersedia menjadi responden.

Jenis penelitian menggunakan metode survei. Instrumen yang digunakan dalam penelitian ini menggunakan kuesioner yang berisi pertanyaan-pertanyaan bersifat umum yang belum pernah ditanyakan pada penelitian sebelumnya. Adapun surveinya dalam bentuk kuisioner yang dibuat dalam bentuk google form agar mudah diakses oleh mahasiswa berupa pilihan ganda dan pertanyaan dengna jawaban singkat.

Pertanyaan-pertanyaan yang diajukan meliputi pertanyaan mengenai aspek motivasi belajar dan kemandirian dalam belajar. Aspek motivasi meliputi kesiapan dalam belajar, keingintahuan dengan mempelajari bahan kuliah sebelum kuliah dilaksanakan, adakah perasaan terganggunya kegiatan rutin dengan perubahan metode belajar dari metode konvensional beralih ke metode daring, lamanya konsentrasi selama kuliah dan ruangan yang digunakan untuk kuliah agar mahasiswa merasa nyaman selama proses pembelajaran. Sedangkan aspek kemandirian meliputi pertanyaan tentang perilaku mahasiswa dalam hal mengakses bahan kuliah dalam bentuk e-book, bahan kuliah dosen dalam bentuk power point ataupun jurnal-jurnal terkait dengan topik kuliah tersebut, sistem belajar yang dipilih selama e-learning dan adakah bantuan dari orang sekitarnya (orang tua, teman ataupun saudara) dalam mengerjakan tugas kuliah. Aspek selanjutnya adalah pertanyaan adanya gangguan kesehatan yang dirasakan selama 
melakukan proses pembelajaran secara daring. Gangguan kesehatan yang dirasakan mulai dari gejala ringan seperti pegal-pegal di otot dan seluruh tubuh hingga gangguan sistemik seperti gangguan pada mata, perasaanm mual, ingin muntah, keluhan pusing dan sebagainya (Fitriyani, Fauzi, dan Sari, 2020).

Data diolah menggunakan aplikasi IBM SPSS statistic Version 22. Analisis univariat digunakan untuk melihat distribusi frekuensi dari setiap butir pilihan dalam menjawab pertanyaan.

\section{Hasil Penelitian}

Setelah dilakukan penyebaran kuesioner melalui aplikasi google form yang dapat diunduh sendiri oleh mahasiswa FK YARSI selama proses e-learning pada bulan September-November 2020, terdapat 310 mahasiswa peserta perkuliahan blok endokrin, nutrisi dan metabolisme. Mahasiswa yang mengisi kuesioner sebanyak 220 orang (71\%).
Grafik 1 menjabarkan pertanyaan apakah penyerapan ilmu selama e-learning berlangsung dengan baik, terdapat 40\% mahasiswa yang menjawab cukup, karena materinya dapat didownload sendiri di internet, sedangkan $27 \%$ merasakan penyerapan materi berlangsung dengan baik karena dosen mengajar dengan baik, lalu 25\% mahasiswa menyatakan kurang dapat menyerap pelajaran karena dosen tidak mengajar secara tatap muka. Sebanyak $4,5 \%$ mahasiswa menjawab penyerapannya sangat baik karena dosen mengajar secara langsung ke pokok materinya. Grafik 2 menjabarkan pertanyaan mengenai kesiapan dalam mempelajari topik kuliah sebelum e-learning, dijawab siap oleh $48 \%$ mahasiswa karena mereka telah membaca materi selama 10-15 menit sebelumnya dan 25\% mahasiswa telah membaca selama 15-30 menit sebelumnya. Sedangkan 19\% menjawab tidak siap karena mereka belum pernah membaca materi kuliah sebelum e-learning.

\section{Penyerapan Materi selama E-learning}

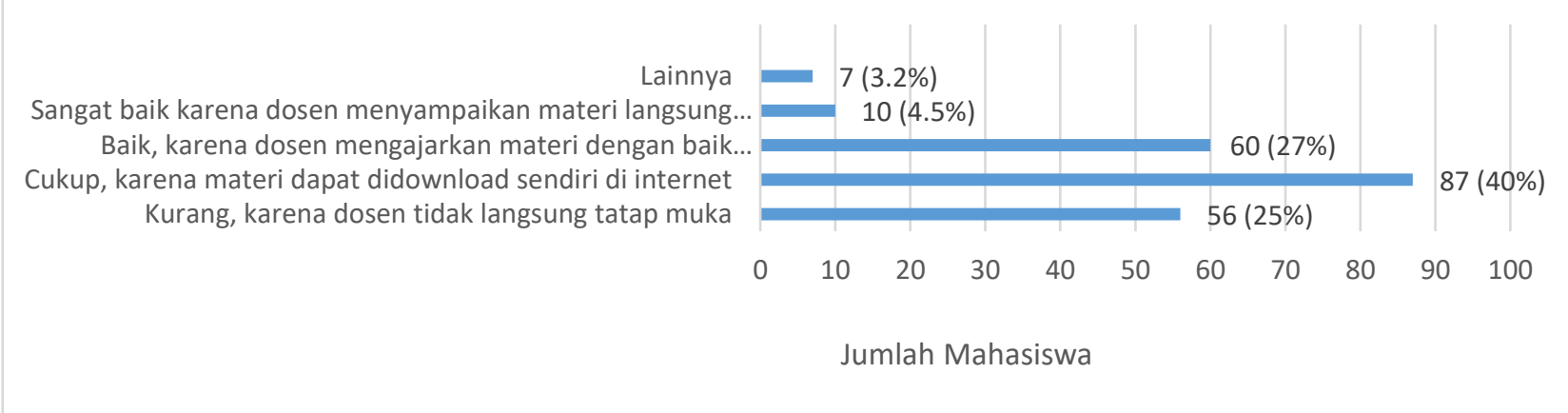

Grafik 1. Penyerapan Materi secara E-Learning 


\section{Kesiapan Mahasiswa dalam Mempelajari Materi sebelum E-learning}

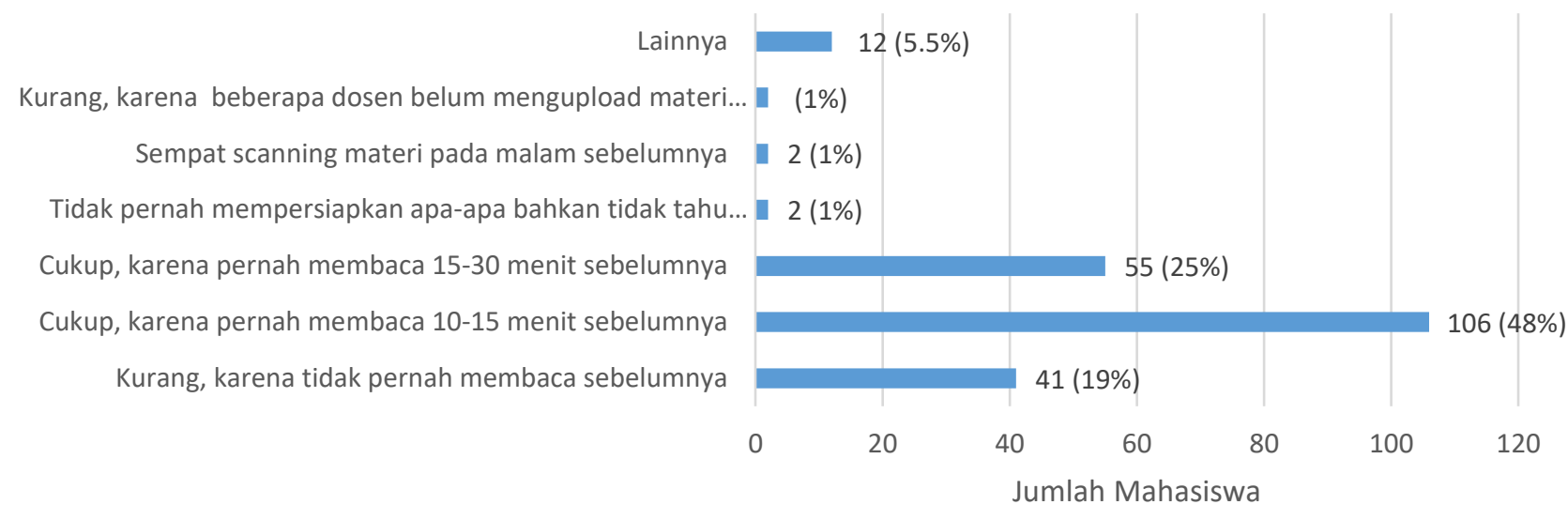

Grafik 2. Kesiapan Mahasiswa Mempelajari Materi Kuliah sebeum E-learning

Alasan tidak siap membaca materi sebelum e-learning adalah karena beberapa dosen belum mengupload materi kuliahnya di website e-learning (www.layar YARSI.go.id), atau sudah membacanya tapi belum mengerti materinya, tidak sempat karena banyak tugas atau hanya membaca sebagian materi karena banyaknya materi yang harus dibaca untuk $e$ learning keesokan harinya.

Grafik 3 menjawab pertanyaan mengenai apakah e-learning mengganggu aktivitas rutin mahasiswa seahri-hari. Sebanyak 49\% mahasiswa tidak merasakan bahwa kuliah e-learning mengganggu aktivitas rutin hariannya karena mereka sudah dapat mengatur waktunya dengan baik. Sedangkan $42 \%$ mahasiswa merasakan kuliah e-learning agak mengganggu aktivitas rutin hariannya karena kadang-kadang dosen menjadualkan ulang kuliahnya. Alasan lainnya adalah kegaitan rutin terganggu karena waktu kuliah yang diberikan tidak sesuai dengan yang sudah dijadualkan sebelumnya, kuis diberikan waktu malam hari sehingga mengganggu jadual harian serta lokasi rumah di Indonesia Timur yang tidak sesuai dengan waktu kuliah di Indonesia Barat.

Grafik 4 menjelaskan lamanya konsentrasi mahasiswa selama e-learning paling lama 2-3 jam saja (36\% mahasiswa), sedangkan $31 \%$ mahasiswa hanya dapat berkonsentrasi selama 1-2 jam saja, sebanyak 18\% mahasiswa dapat konsentrasi lebih lama yaitu 3-4 jam, bahkan 9\% mahasiswa menyatakan dapat konsentrasi selama 4-6 jam selama belajar secara e-learning; lainnya menyatakan hanya dapat berkonsentrasi selama 30 menit bahkan kurang dari 30 menit. 


\section{Pelaksanaan E-Learning dan Waktu untuk Aktivitas Rutin}

Terkadang mengganggu karena kuis sering dilakukan pada malam hari, dan terkadang reschedule kelas di hari libur

Sangat mengganggu, karena kuis dan ujian sering dilakukan di sore dan malam hari di luar jadual kuliah yang sudah ditetapkan sebelumnya

Sangat mengganggu karena ritme harian saya seperti waktu tidur, istirahat, belajar, mengerjakan hobi terganggu

Ya, agak mengganggu karena PJJ kadang-kadang tidak sesuai dengan jadual yang sudah ditetapkan sebelumnya Tidak, saya dapat mengatur waktu dengan baik
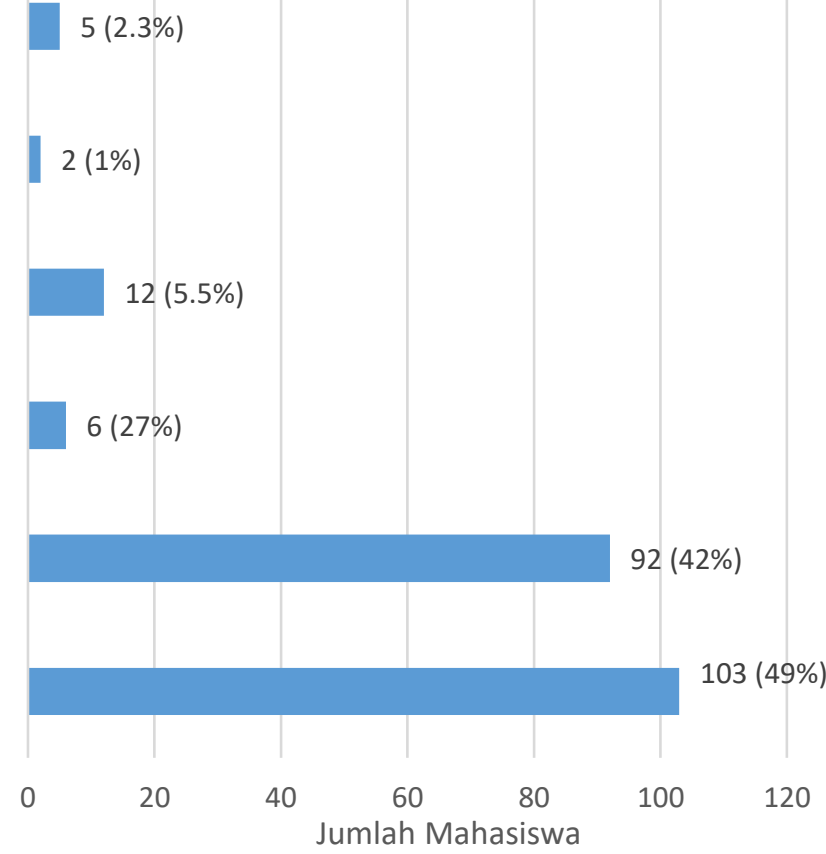

Grafik 3. Pelaksaan E-Learning dan Waktu untuk Pelaksanaan Aktivitas Rutin

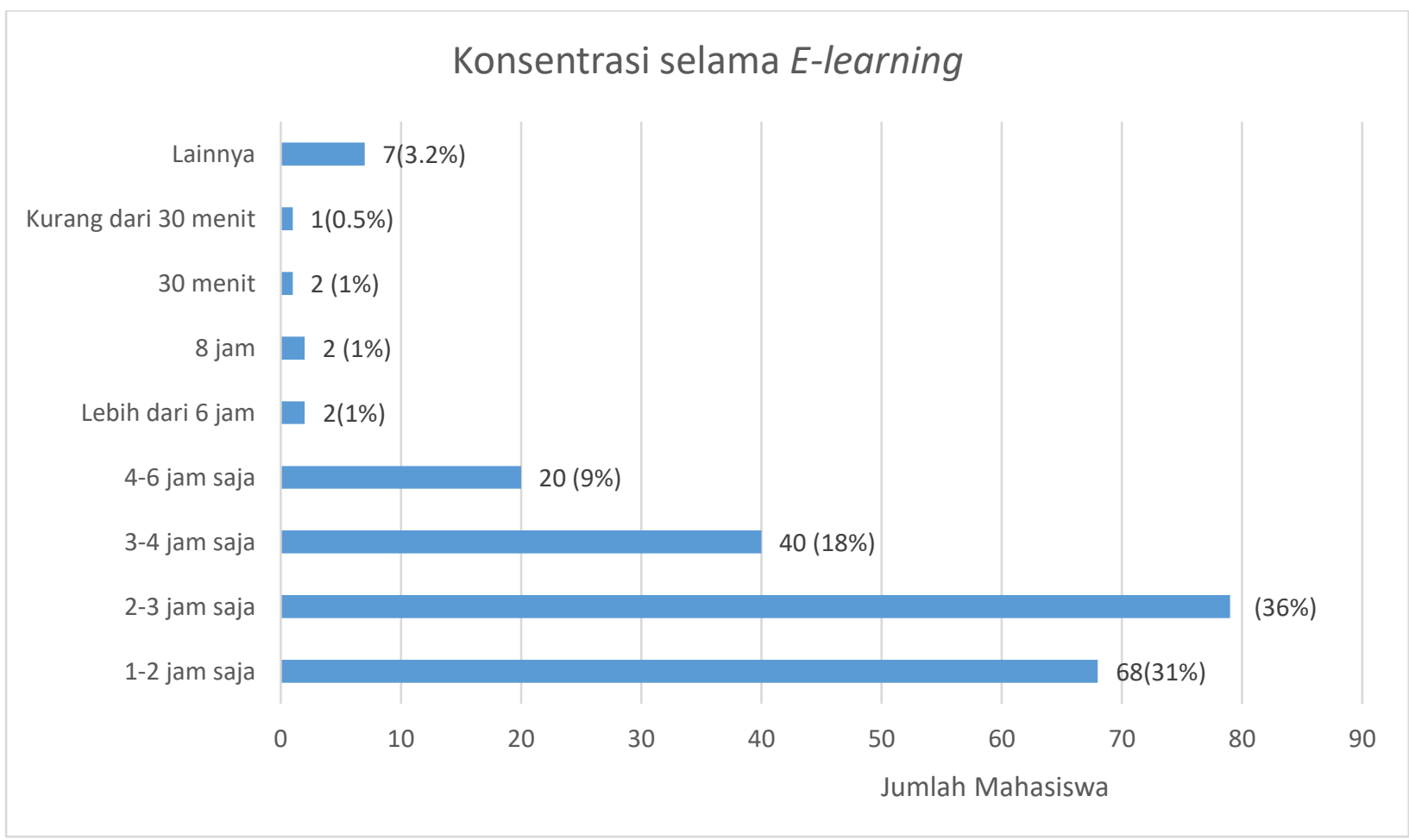

Grafik 4. Lamanya Waktu Konsentrasi saat E-learning 
Grafik 5 menjabarkan keluhan mahasiswa selama e-learning yang terbanyak adalah leher kaku, pusing, dan pegal-pegal diseluruh tubuh (40\%), 38\% mahasiswa mengeluh mata terasa kabur, perih dan lelah. Tetapi sebanyak 12\% mahasiswa tidak merasakan adanya gangguan kesehatan selama e-learning. Sisanya merasakan pinggang dan punggung sakit akibat terlalu lama dalam posisi duduk, keluhan sakit telinga karena terlalu lama memakai handphone, vertigo, mual dan muntah.

Grafik 7 memaparkan bahwa sebanyak 47\% mahasiswa menyebutkan dapat dengan mudah memperoleh buku-buku dan mengakses materi e-learning karena dosen sudah menyediakan materinya dalam bentuk power point, artikel jurnal dan buku-buku yang tersedia di situs e-learning Universitas YARSI, 30\% mahasiswa lainnya menyebutkan kemudahan mengakses bahan kuliah tanpa menyebutkan alasannya, sisanya menyebutkan mudah tapi penjelasan yang diperolehnya kurang detil (1\%) dan mudah diakses website untuk e-learning tapi ada dosen yang belum mengupload bahan kuliahnya. Sedangkan $12.3 \%$ mengatakan sulitnya mendapatkan akses materi e-learning dan $8.2 \%$ menyebutkan kesulitan itu terjadi karena situsnya berbayar.

Terdapat hal yang menggembirakan karena 69\% mahasiswa Fakultas Kedokteran Universitas YARSI tetap belajar berkelompok dengan teman secara daring selama e-learning (grafik 7). Sedangkan 25\% mahasiswa mengatakan tidak memerlukan bantuan sama sekali selama e-learning, baik dari teman sekelompok, orang tua ataupun saudaranya. Bantuan belajar juga diperoleh dengan melihat situs youtube $(0.05 \%)$. Bantuan dari orang tua dan orang sekitar mereka di rumah hampir tidak adal, hanya sesekali (5\%), bahkan ada yang mengatakan orang di sekitarnya tidak bisa membantu mereka. Hal ini terjadi karena pelajaran di Fakultas Kedokteran tergolong sulit, maka diperlukan kelompok belajar secara daring. Bagi mahasiswa Fakultas Kedokteran, belajar berkelompok tetap diperlukan meskipun secara virtual. Hal ini sangat baik untuk mengurangi beban akademik dan stres di antara mahasiswa.

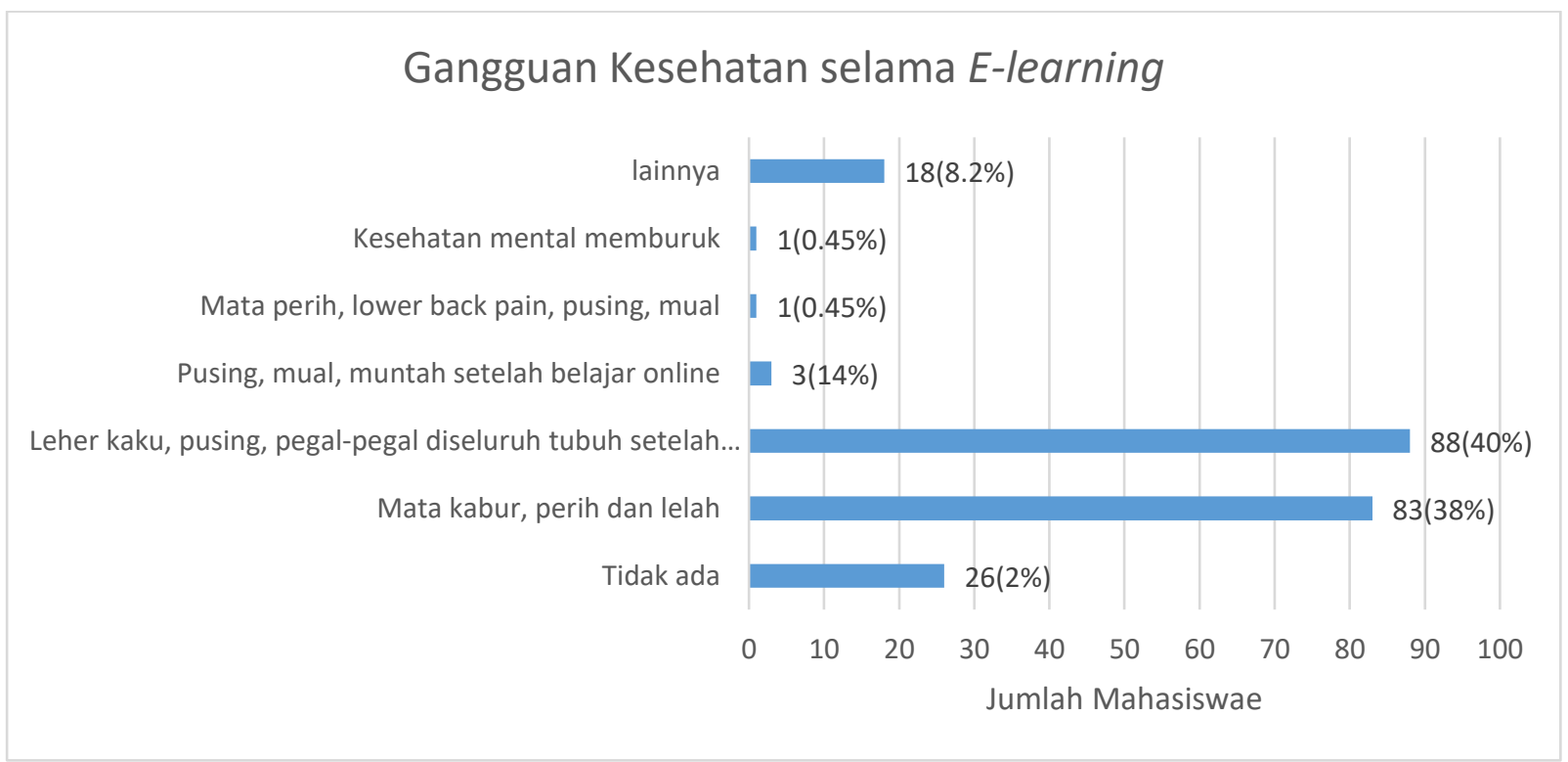

Grafik 5. Gangguan Kesehatan selama E-Learning 


\section{Kemudahan Mengakses Materi E-learning}

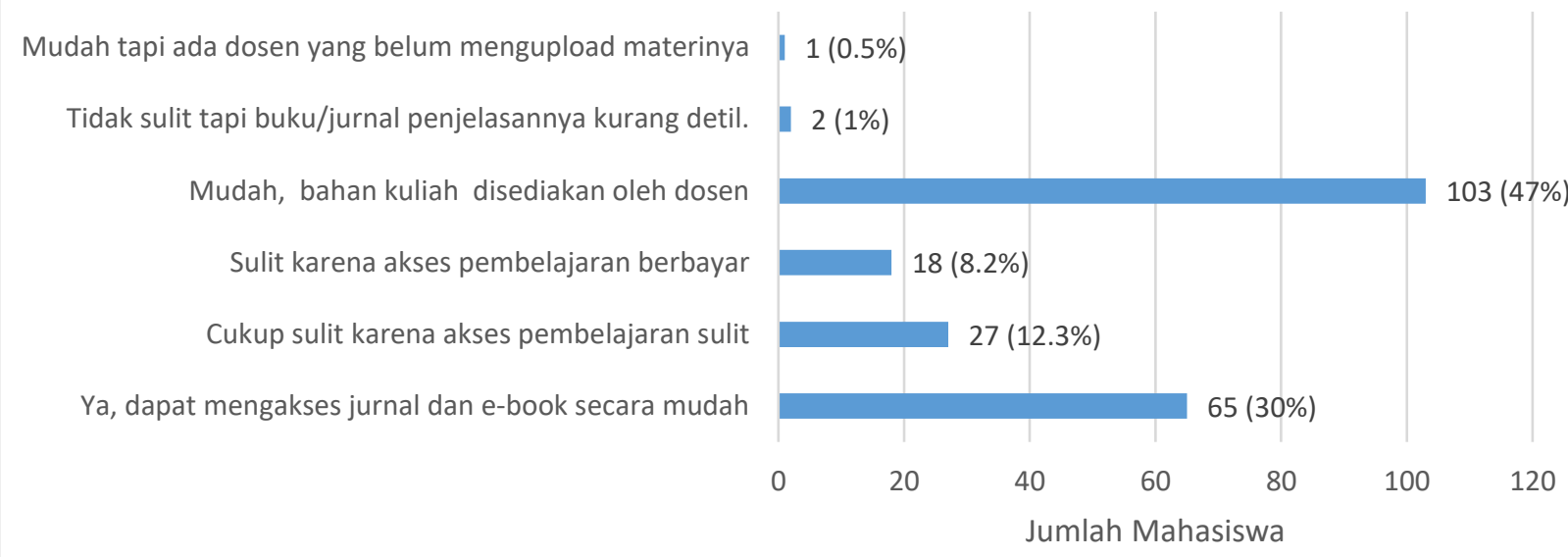

Grafik 6. Kemudahan Mengakses Materi E-learning

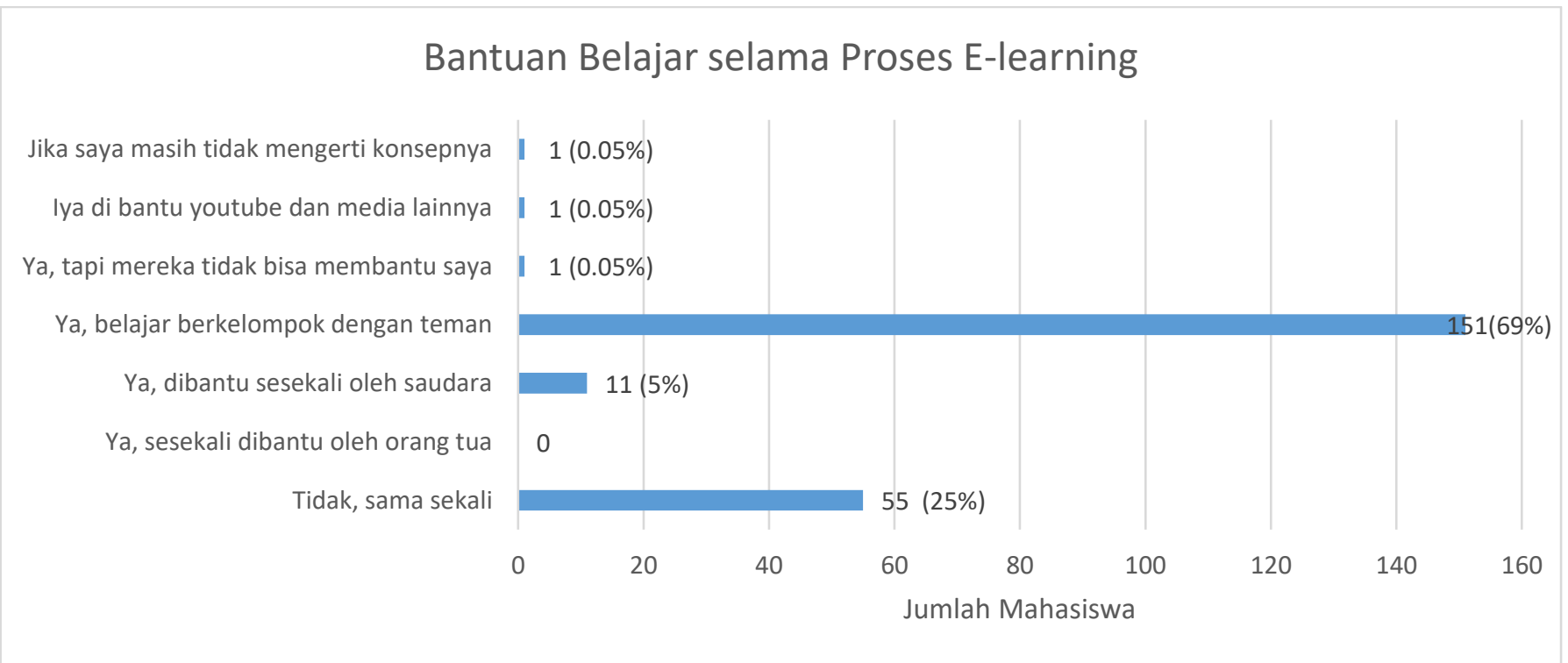

Grafik 7. Bantuan Belajar selama Proses E-learning

Pelaksanaan e-learning yang paling disukai adalah dalam kamar tidur (89\%), karena kamar tidur dilengkapi dengan buku-buku yang memudahkan untuk mempelajari e-learning dan tempat mahasiswa merasa nyaman dan memiliki privacy. Sedangkan 9\% mahasiswa melakukan e-learning di ruang tamu atau ruang keluarga.

Berdasarkan kuesioner didapatkan jawaban bahwa sebagian besar mahasiswa
Fakultas Kedokteran Universitas YARSI lebih menyukai kuliah tatap muka langsung dibandingkan dengan e-learning (56\%). Hanya $12 \%$ mahasiswa yang menyatakan lebih menyukai e-learning dibandingkan dengan kuliah tatap muka langsung. Sebanyak 32\% menyatakan menyukai keduanya, baik sistem pembelajaran e-learning maupun tatap muka (grafik 8). 


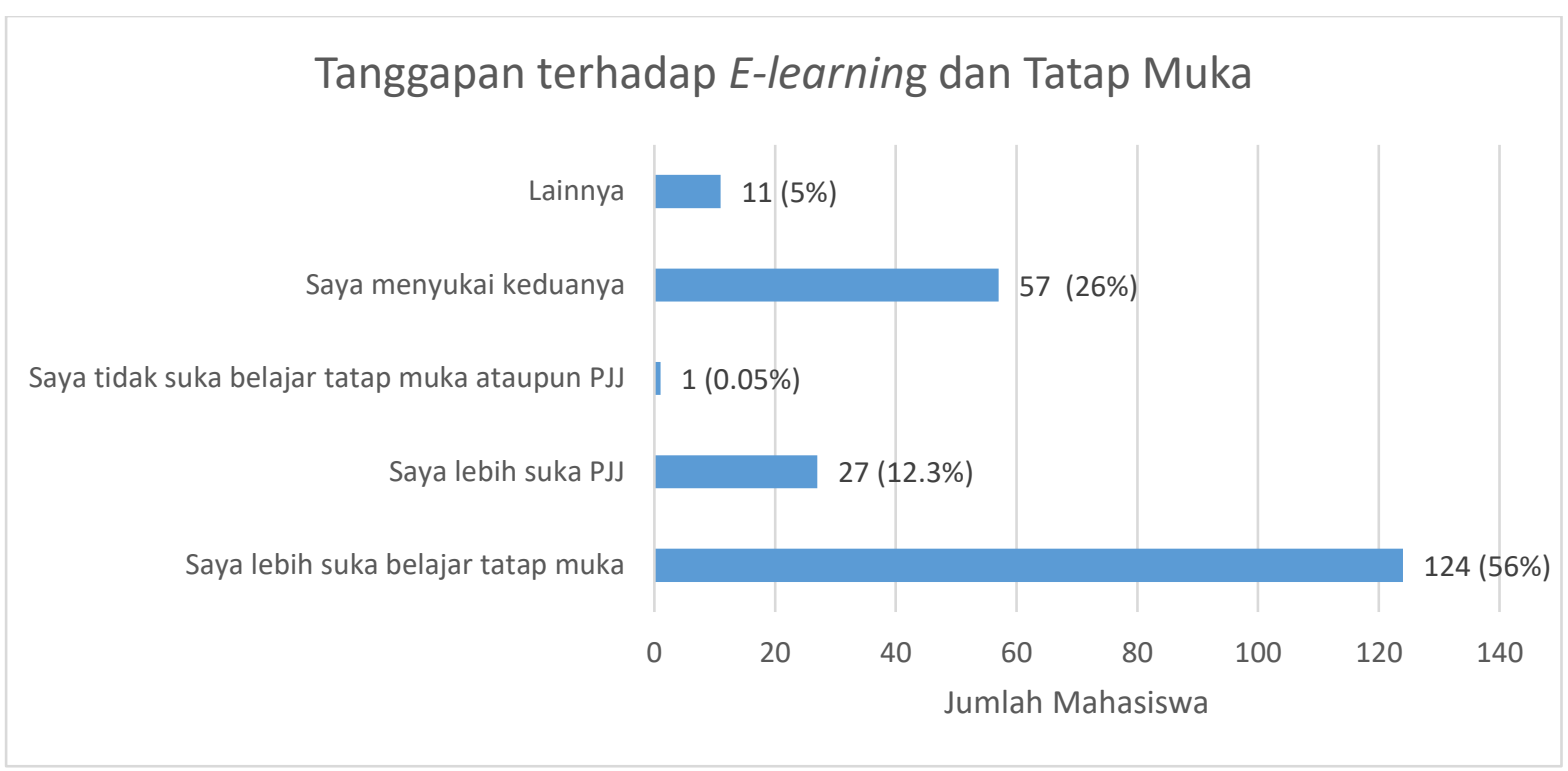

Grafik 8. Tanggapan terhadap e-Learning dan tatap muka

Mahasiswa yang menyatakan lebih menyukai tatap muka langsung dibandingkan dengan e-learning berpendapat bahwa tatap muka tidak membuat bosan, materi lebih mudah dimengerti, ada waktu untuk bertemu dosen secara langsung,tidak ada kendala sinyal dan lebih daapt berkonsentrasi. Sedangkan mahasiswa yang berpendapat lebih menyukai elearning dibandingkan tatap muka secara langsung karena waktu pelaksanaan e-learning lebih fleksibel, dosen sudah mengupload bahan kuliahnya di situs e-learning Universitas YARSI, dan saat dosen memberiakn kuliah bisa direkam.

\section{Diskusi}

Penyerapan ilmu selama e-learning berlangsung dengan baik, terdapat 40\% mahasiswa yang menjawab cukup $\mathrm{Hal}$ ini agak berbeda dengan hasil penelitian mahasiswa IAIN Padangsidimpuan Sumatra Utara sebanyak $83,6 \%$ menjawab tidak mudah mempelajari dan menyerap materi pelajaran selama e-learning, hanya sebanyak $16,4 \%$ yang menjawab dapat menyerap materi e-learning dengan mudah.Faktor penyebab materi pelajaran kurang dapat diserap dengan baik adalah kesulitan akses materi yang disampaikan oleh dosen sebelum e-learning berlangsung (Napitupulu, 2020). Universitas YARSI telah memiliki website resmi yang memudahkan dosen untuk mengupload materi kuliah ataupun memberikan link materi sebelum e-learning berlangsung, sehingga memudahkan mahasiswa untuk mengaksesnya.

Pertanyaan mengenai kesiapan dalam mempelajari topik kuliah sebelum e-learning, dijawab siap oleh 48\% mahasiswa karena mereka telah membaca materi selama 10-15 menit sebelumnya. Data penelitian yang dilakukan pada mahasiswa FKIP Universitas Sulawesi Barat oleh Firman dan Rahayu (2020), mendapat hasil bahwa banyak mahasiswa yang kesulitan dalam memahami materi kuliah yang diberikan secara online. Mereka merasakan kebutuhan untuk berkomunikasi secara langsung dengan dosen, tidak hanya belajar mandiri melalui tugas baca.

Sebanyak 49\% mahasiswa tidak merasakan bahwa kuliah e-learning mengganggu aktivitas rutin hariannya karena mereka sudah dapat mengatur waktunya dengan baik.Pengaturan waktu belajar $e$ - 
learning agar tidak mengganggu aktivitas rutin harian merupakan bagian dari kemandirian seorang mahasiswa. Mahasiswa yang secara mandiri menyadari bahwa pembelajaran $e$ learning akan berbeda dengan tatap muka langsung tentu dapat mengatur waktunya dengan baik. Penelitian yang dilakukan oleh Napitupulu (2020) pada mahasiswa di Sumatra Utara menyebutkan hanya 27,9\% mahasiswa yang memiliki kemandirian belajar selama e-learning, termasuk masalah pengaturan waktu.

Lamanya konsentrasi mahasiswa selama e-learning paling lama 2-3 jam saja (36\% mahasiswa). Hal ini sesuai dengan penelitian yang dilakukan oleh Mustakim (2020) yang menyebutkan bahwa 56,7\% murid SMA di SMAN I Waji, Sulawesi Selatan menyatakan sulit fokus selama e-learning karena bosan, mata lelah, mengantuk, sakit kepala, badan pegal dan sulit istirahat. Keluhan mahasiswa selama e-learning yang terbanyak adalah leher kaku, pusing, dan pegalpegal diseluruh tubuh (40\%), 38\% mahasiswa mengeluh mata terasa kabur, perih dan lelah. Penelitian yang dilakukan oleh Yikealo menyebutkan bahwa mahasiswa dapat mengalami stres dalam belajar, tidak hanya dalam bentuk stres mental tetapi juga stres secara fisik berupa gangguan kesehatan dengan gejala-gejala: kelelahan, nafsu makan menurun, back pain, masalah pencernaan, demam, insomnia, sistem urinaria, sakit kepala dan denyut jantung meningkat, dan masalah sistem pernafasan. Stres tersebut akan mempengaruhi keberhasilan belajar mahasiswa (Putri, Oktaviani, Utami dkk, 2020). Penelitian pada mahasiswa Fakultas Kedokteran Universitas Samratulangi mengenai hubungan lama waktu penggunaan laptop dengan keluhan penglihatan mata terasa gatal, mata terasa nyeri, mata tegang atau lelah, mata berair, rasa silau, penglihatan kabur atau berbayang, dan sakit kepala tidak berhubungan secara signifikan karena tergantung dari status kesehatan mata mahasiswa sebelumnya, posisi duduk, adanya jeda saat melihat laptop, dan sebagainya (Kurmasela, Saerang, dan Rayes, 2013).

$$
\text { Sebanyak } 47 \% \text { mahasiswa }
$$

menyebutkan dapat dengan mudah memperoleh buku-buku dan mengakses materi e-learning. Hal ini sesuai dengan hasil penelitian pada mahasiswa FMIPA UNPAD Bandung yang memiliki sikap aktif mencari bahan sumber lain yang terkait materi e-learning yang merupakan bagian dari kemandirian sikap dalam belajar (Kusuma, 2020).

Mahasiswa Fakultas Kedokteran Universitas YARSI lebih menyukai kuliah tatap muka langsung dibandingkan dengan e-learning (56\%). Hal ini sesuai dengan hasil penelitian Napitupulu (2020) pada mahasiswa IAIN Sumatra Utara yang sebagian besar menyatakan tidak puas dalam hal e-learning dengan alasan tidak siap dengan peralihan tibatiba dari tatap muka ke metode e-learning, kesulitan mengakses materi, ketidaksiapan dosen dalam memberikan kuliah dan masih menginginkan kuliah tatap muka langsung. Berdasarkan petanyaan terbuka yang diajukan maka beberapa mahasiswa yang lebih menyukai e-learning memiliki alasan tidak perlu susah bangun pagi untuk ke kampus, lebih banyak waktu untuk berkumpul dengan keluarga, bagi yang pemalu menguntungkan karena jika ingin bertanya kepada dosen tidak perlu tatap muka langsung dan mereka lebih dapat mengatur waktunya untuk kegiatan lain. Akan tetapi materi kuliah yang banyak, serta sulitnya materi dimengerti dan tugas yang menumpuk membuat 
mahasiswa merasa sulit melakukan e-learning. Hal ini sesuai dengna meta analisis yang dilakukan pada mahasiswa Fakultas Kedokteran di Inggris yang lebih menyukai kuliah tatap muka langsung karena adanya keterbatasan dalam menyampaikan pertanyaan, gangguan dari keluarga, kecemasan, masalah waktu tutorial, koneksi internet dan keterbatasan ruang (Dost, Hossain, Shehab dkk, 2020). Penelitian pada 382 mahasiswa fakultas Kedokteran Gigi di Liaquat College of Medicine and Dentistry Pakistan memperoleh hasil bahwa 77\% mahasiswa tidak menyukai kuliah online karena mereka belum siap (Abbasi, Ayoob, Malik, dkk, 2020).

Pendapat mahasiswa Fakultas

Kedokteran Gigi Universitas Airlangga menyatakan bahwa mereka menyukai kuliah $e$ learning secara online dengan metode video conference karena dapat membantu meningkatkan rasa percaya diri dan mengurangi batas ruang dan waktu dalam perkuliahan. Sebagian besar mahasiswa beranggapan bahwa jadwal kuliah online sudah teratur dengan baik oleh pihak kampus, baik persiapan, ketepatan waktu, kesesuaian topik dan peran teknisi kampus yang terlibat (Oki, Yuliati, Sunariani dkk, 2020).

\section{Simpulan}

Pelaksanaan e-learning pada
mahasiswa Fakultas Kedokteran YARSI memberikan gambaran sebagai berikut: penyerapan materi kuliah berlangsung dengan baik pada $40 \%$ mahasiswa, kesiapan mahasiswa dalam mempersiapkan materi sebelum $e$ learning sebagian besar berlangsung dengan baik karena mereka telah membaca materinya paling tidak selama 10-15 menit sebelum elearning (48\%), sebagian besar mahasiswa dapat mengatur waktu dengan baik selama $e$ learning sehingga tidak mengganggu aktivitas rutin hariannya $(47 \%)$, mahasiswa dapat berkonsentrasi penuh saat e-learning sebagian besar hanya 2-3 jam saja (36\%), gangguan kesehatan terbanyak yang dirasakan oleh $40 \%$ mahasiswa selama proses e-learning adalah leher kaku, pusing dan pegal-pegal, sebanyak $47 \%$ mahasiswa menyatakan kemudahan memperoleh buku-buku, akses jurnal, text book dan materi di situs e-learning Universitas YARSI sebagai bahan kuliah selama e-learning, sebagian besa mahasiswa (69\%) melakukan pembelajaran secara berkelompok selama $e$ learning, dan sebagian besar mahasiswa Fakultas Kedokteran Universitas YARSI (56\%) lebih menyukai cara pembelajaran konvensional (tatap muka langsung) dibandingkan secara $e$ learning.

Keterbatasan penelitian ini terletak pada metode penelitian secara cross sectional karena tidak ada kelompok pembanding yang mengevaluasi persepsi mahasiswa terhadap metode belajar e-learning dibandingkan dengan kelompok yang belajar secara tatap muka langsung. Masih diperlukan penelitian lebih lanjut terhadap mahasiswa dengan semester yang berbeda dan blok mata kuliah yang berbeda untuk mengetahui persepsi mereka terhadap e-learning. Sebagai saran diperlukan penelitian mengenai persepsi mahasiswa untuk tiap mata kuliah yang terlibat secara lebih detil mengenai kesiapan dosen yang terlibat, bahan ajar yang dipakai dan fasilitas pembelajaran yang tersedia di tiap bagian seperti penelitian yang dilakukan pada mahasiswa Fakultas Kedokteran Universitas Airlangga yang mendapatkan hasil bahwa perkuliahan anatomi berlangsung dengan baik yang meliputi, keterlibatan dosen, bahan kuliah, fasilitas 
pembelajaran dan usaha mahasiswa untuk belajar (Zakira, 2019).

\section{Daftar Pustaka}

Abbasi S, Ayoob T, Malik A, Memon SI. 2020. Perceptions of students regarding $E$ learning during Covid-19 at a private medical college. Pak J Med Sci. May; 36(COVID19-S4): S57-S61.

Dost S, Hossain A, Shehab M, Abdelwahed A, Al-Nusair R. 2020. Perceptions of medical students towards online teaching during the COVID-19 pandemic: a national crosssectional survey of 2721 UK medical students. BMJ Open;10:e042378.

Firman dan Rahman SR. 2020. Pembelajaran Online di Tengah Pandemi Covid-19. Indonesian Journal of Educational Science (IJES). Vol. 02, No.02:81-89.

Fitriyani Y, Fauzi, Sari MZ. 2020. Motivasi Belajar Mahasiswa Pada Pembelajaran Daring Selama Pandemik Covid-19. Jurnal Kependidikan: Jurnal Hasil Penelitian dan Kajian Kepustakaan di Bidang Pendidikan, Pengajaran dan Pembelajaran, Vol.6, No.2,: 165-175.

Kurmasela GP, Saerang JSM dan Rayes L. 2013. Hubungan Waktu penggunaan Laptop dengan Keluhan Penglihatan pada Mahasiswa Fakultas Kedokteran Universitas Sam Ratulangi. Jurnal eBiomedik (eBM), Volume 1, Nomor 1: 291299.

Kusuma DA. 2020. Dampak Penerapan Pembelajaran Daring terhadap Kemandirian Belajar (Self-Regulated learning) Mahasiswa pada Mata kuliah Geometri selama pembelajaran Jarak Jauh di Masa Pandemi Covid-19. Teorema: Teori dan Riset Matematika, 5(2):169-175.

Mustakim 2020. Efektivitas pembelajaran Daring Menggunakan Media Online selama pandemi Covid-19 pada Mata Pelajaran Matematika. Al asa: Journal of islamic Education, Vol.2, No.1 : 1-12.

Napitupulu RM. 2020. Dampak pandemi Covid19 terhadap Kepuasan Pembelajaran Jarak Jauh. Jurnal Inovasi Teknologi Pendidikan, Volume 7, No.1: 23-33.

Oki SA, Yuliati, Sunariani J, Irmawati A, Luthfi M. 2020. Dental students' perception of online lecture on video conference. Sys Rev Pharm, 11 (12): 245-248.

Poon J. 2013. Blended Learning: an institutional approach for enhancing students' learning experiences. MERLOT Journal of Online Learning and Teaching, 9 (2).

Putri RM, Oktaviani AD, Utami ASF, Ni'maturrohmah, Addiina $\mathrm{HA}$, Nisa $\mathrm{H}$. 2020. Hubungan Pembelajaran Jarak Jauh dan gangguan Somatoformdengan Tingkat Stres Mahasiswa UIN Syarif Hidayatullsh Jakarta. Perilaku dan Promosi Kesehatan: Indonesian Journal of Health Promotion and Behavior ; 2(1): 3845.

Zakira A. 2018. Persepsi mahasiswa terhadap lingkungan pendidikan e-learning di bidang anatomi Fakultas Kdokteran Airlangga. Tesis, Diunduh dari http://repository.unair.ac.id/78394/ 